\title{
Porsasvaiheen ripulihavaintojen yhteys lihasikojen kasvuun ja teurasominaisuuksiin
}

\author{
Marja-Liisa Sevón-Aimonen ${ }^{1)}$, Liisa Voutila ${ }^{2)}$, Jarkko Niemi ${ }^{3)}$ ja Kirsi Partanen ${ }^{4)}$ \\ ${ }^{1)}$ MTT, Biotekniikka- ja elintarviketutkimus, Alimentum, 31600 Jokioinen, \\ marja-liisa.sevon-aimonen@mtt.fi \\ ${ }^{2)}$ MTT, Kotieläintuotannon tutkimus, Tervamäentie 179,05840 Hyvinkää, liisa.voutila@mtt.fi \\ ${ }^{3)}$ MTT, Taloustutkimus, Kampusranta 9, 60320 Seinäjoki, jarkko.niemi@mtt.fi \\ ${ }^{4)}$ MTT, Kotieläintuotannon tutkimus, Tervamäentie 179, 05840 Hyvinkää, \\ kirsi.partanen@mtt.fi
}

\section{Tiivistelmä}

Porsaiden ripulit ovat varsinkin vieroitusvaiheessa yleisiä. Ne aiheuttavat jonkin verran kuolleisuutta ja hidastavat porsasvaiheen kasvunopeutta. Se miten ripuli vaikuttaa myöhempään kasvuun ja teurasominaisuuksiin, jää usein selvittämättä, koska porsasvaiheen tiedot eivät seuraa porsaan mukana myöhempiin vaiheisiin.

Tässä kokeessa seurattiin porsasajan ripulin vaikutusta sekä välitysvaiheen kasvuun, lihasikavaiheen kasvuun sekä teurasominaisuuksiin Rotupossu-hankkeessa kerätyn aineiston pohjalta. Koe tehtiin MTT:een Hyvinkään koesikalassa. Ripulihavainnot oli kerätty karsinakohtaisesti päivittäin vieroituksen jälkeen välikasvatusvaiheessa. Keston lisäksi myös ripulin vaikeusaste merkittiin ylös ja ripulin kestoa ja vaikeutta kuvaamaan käytettiin näistä muodostettua ripuli-indeksiä. Ripulitiedot koostettiin selittäviksi muuttujiksi summaamalla ripuli-indeksit (0-40) ja jakamalla ne seitsemään luokkaan. Täydelliset kasvu- ja teurastiedot oli koottu sekä varsinaiseen rotuvertailuun otetuille (311 sikaa) että rotuvertailututkimuksessa syntyneille, mutta kokeen ulkopuolella kasvatetuille porsaille (439 sikaa). Koska vaikutukset olivat molemmissa osaaineistossa samansuuntaiset ja ripulihavainnot oli tehty vaiheessa, kun porsaita ei ollut jaettu kokeeseen, kaikki siat käsiteltiin yhdessä. Aineisto analysoitiin SAS 9.2 ohjelmistolla käyttäen sekamallia. Mallissa oli satunnaistekijänä pahnue, ja kiinteinä rotu, sukupuoli, koeluokka (rotuvertailu tai muu käyttö) ja luokiteltu ripuli-indeksi sekä kiinteiden tekijöiden yhdysvaikutukset. Yhdysvaikutukset eivät olleet tilastollisesti merkitseviä, joten ne jätettiin lopullisissa analyyseissä pois. Tutkitut muuttujat olivat kasvunopeus vieroituksesta välitykseen (välikasvatusvaihe), kasvunopeus välityksestä teurastukseen (lihasikavaihe), lihaprosentti ja teurastappio.

Ripulihavaintoja oli eniten kahden viikon sisällä vieroituksesta, jonka jälkeen ne olivat harvinaisia. Välitysvaiheen kasvunopeuteen ei ripuli-indeksillä ollut mitään vaikutusta. Paras lihasikavaiheen kasvu oli jonkin verran ripulia sairastaneiden karsinoiden porsailla. Voimakas ja pitkäkestoinen ripuli (ripuliluokka 6 7) näytti heikentävän kasvunopeutta, mutta tämäkään vaikutus ei ollut tilastollisesti merkitsevä. Lihaprosentti näytti hieman paranevan ripuli-indeksiluokan kasvaessa. Teurastappion ja ripulin välillä ei ollut havaittavissa mitään yhteyttä. Vaikka rotuyhdistelmissä oli jonkin verran eroja ripuliin sairastuvuudessa, ei ripulin huomioon ottaminen tilastollisessa mallissa vaikuttanut rotuyhdistelmien eroihin. Koska ripulihavainnot olivat pahnue/karsinakohtaisia, ne eivät täysin kuvaa yksittäisen eläimen sairastavuutta ja sen vaikutusta mitattuihin ominaisuuksiin. Porsaat kuitenkin jakaantuivat välikasvatuksen jälkeen useaan karsinaan ja ruokinnoille, jonka vuoksi esim. pahnueen keskiarvotuloksia ei voitu käyttää yksilötulosten sijasta tuotantotulosten kuvaajana.

Tässä tutkimuksen sikojen lievällä vieroitusripulilla ei ollut tilastollisesti merkitsevää vaikutusta sikojen kasvuun eikä teurasominaisuuksiin eikä myöskään rotuvertailun tuloksiin.

Asiasanat: sika, vieroitusripuli, kasvunopeus, teuraslaatu 


\section{Johdanto}

Porsaiden ripulit ovat varsinkin vieroitusvaiheessa yleisiä. Vieroitusripulit aiheuttavat jonkin verran kuolleisuutta ja hidastavat porsasvaiheen kasvunopeutta. Se miten ripuli vaikuttaa myöhempään kasvuun ja teurasominaisuuksiin, jää usein selvittämättä, koska porsasvaiheen tiedot eivät seuraa porsaan mukana myöhempään vaiheeseen. Rotupossuhankkeessa seurattiin porsaiden ripuleita karsinoittain. Aineisto ja koeasetelma eivät riitä risteytysyhdistelmien ripulialttiuden vertailuun, mutta sen avulla voi silti tarkastella porsasvaiheen ripulin yhteyttä myöhempiin tuotantotuloksiin ja myös rotuvertailun tuloksiin. Tavoite oli selvittää, onko karsinakohtaisilla ripulihavainnolla yhteyttä sikojen tuotanto- ja teurasominaisuuksiin ja onko havainnoilla vaikutusta rotuvertailun tuloksiin.

\section{Aineisto ja menetelmät}

Aineistona olivat Rotupossu-hankkeen (Niemi ym. 2010) varsinaiset rotuvertailun koesiat ja samojen pahnueiden kokeen ulkopuoliset siat. Sikojen emät olivat suomalaisen yorkshiren ja maatiaisen risteytyksiä,ja isät olivat rodultaan tai rotuyhdistelmältään suomenmaatiainen, norjanmaatiainen, duroc-norjanmaatiainen ja hampshire. Koe tehtiin MTT:een Hyvinkään koesikalassa.

Tutkitut muuttujat olivat keskimääräinen päiväkasvu välikasvatuksessa ja lihasikavaiheessa, lihaprosentti ja teurastappio. Ripulihavainnot oli kerätty karsinakohtaisesti päivittäin. Yhdessä karsinassa oli vain saman pahnueen porsaita, mutta suurin osa pahnueista oli jaettu kahteen tai kolmeen karsinaan Tässä käytetty tarkkailujakso alkoi vieroituksesta ja loppui, kun koeporsaat siirrettiin lihasikalaan n. kuuden viikon välikasvatuksen jälkeen. Ripulin keston lisäksi myös vaikeusaste $(0=$ normaali uloste, $1=$ löystynyt puuromainen uloste, 2 = löysä vellimäinen uloste, 3 = vetinen ripuli) merkittiin ylös ja ripulin kestoa ja ripulin vakavuutta kuvaamaan käytettiin näistä tulona muodostettua ripuli-indeksiä. Ripulitiedot koostettiin selittäviksi muuttujiksi summaamalla ripuli-indeksit, ja jakamalla luokkiin viiden pisteen välein. Kasvu- ja teurastiedot oli koottu sekä varsinaiseen rotuvertailuun (311 sikaa) että muille rotuvertailututkimuksessa syntyneille kokeen ulkopuolella kasvatetuille sioille (436 sikaa).

Aineisto analysoitiin SAS ${ }^{9} 9.2$-ohjelmistolla. Mallissa oli satunnaistekijänä pahnue, ja kiinteinä rotu, sukupuoli ja ripulitieto luokiteltuna sekä kiinteiden tekijöiden yhdysvaikutukset. Koska yhdysvaikutukset eivät olleet merkitseviä, ne jätettiin lopullisista analyyseista pois. Lisäksi välikasvatuksen mallissa oli kovariaattina vieroituspaino ja lihasikavaiheen kasvussa välityspaino. Rotuvertailutulosten mahdollisten muutosten tarkastelua varten aineisto ajettiin muutoin samalla mallilla mutta ilman ripulihavaintoa selittävänä muuttujana.

\section{Tulokset ja tulosten tarkastelu}

Muuttujien tunnusluvut on esitetty taulukossa 1. Analyyseissa käytettiin kaikkia havaintoja, joten havaintojen lukumäärät jonkin verran poikkeavat muuttujittain.

Taulukko 1. Porsaiden syntymäpainojen tunnusluvut.

\begin{tabular}{llllll}
\hline & $\mathrm{N}$ & Keski-arvo & Keskihajonta & Minimi & Maksimi \\
\hline Vieroituspaino & 750 & 10,1 & 2,2 & 3,6 & 17,0 \\
Välityspaino & 750 & 27,0 & 2,8 & 19,5 & 42,3 \\
Päiväkasvu välikasvatusvaihe, g/pv & 750 & 437 & 66,7 & 265 & 712 \\
Päiväkasvu lahasikavaihe, g/pv & 750 & 989 & 92,1 & 632 & 1221 \\
Teurastappio, \% & 739 & 60,0 & 2,1 & 50,2 & 65,5 \\
Teurastappio, \% & 744 & 27,4 & 1,8 & 21,5 & 34,8 \\
\hline
\end{tabular}

Ripuli ilmeni yleisimmin pian vieroituksen jälkeen (kuvio 1) ja myös ripulin arvioitiin voimakkaimmaksi pian vieroituksen jälkeen. 


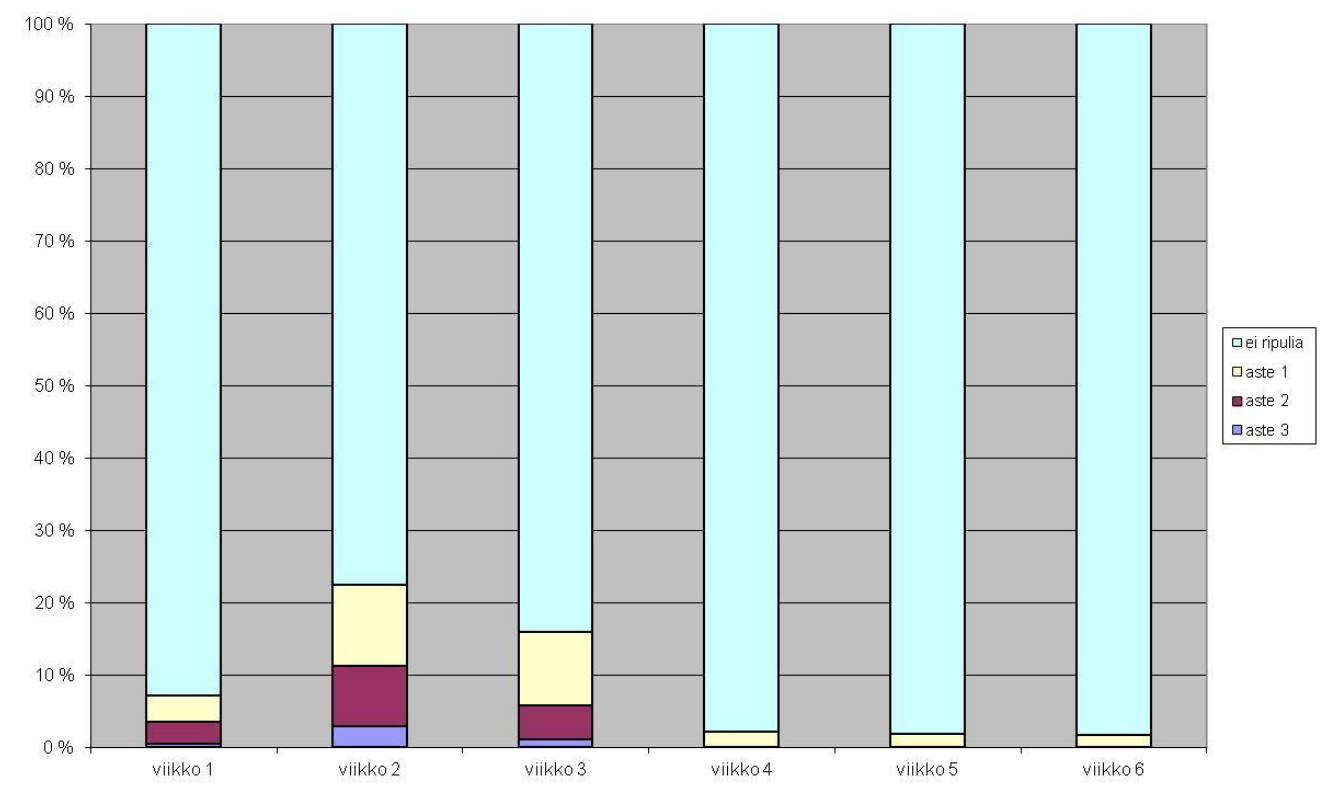

Kuvio 1. Ripulin yleisyys ja vakavuusaste vieroituksen jälkeen (aste 3 pahin).

Luokiteltu ripuli-indeksi ei vaikuttanut merkitsevästi tutkittuihin muuttujiin. Välitysvaiheen kasvunopeuteen ei ripuli-indeksillä ollut mitään vaikutusta. Paras lihasikavaiheen kasvu oli jonkin verran ripulia sairastaneiden karsinoiden porsailla. Voimakas ja pitkäkestoinen ripuli (ripuliluokka 6 -7) näytti heikentävän kasvunopeutta, mutta tämäkään vaikutus ei ollut tilastollisesti merkitsevä. Lihaprosentti näytti hieman paranevan ripuli-indeksiluokan kasvaessa. Teurastappion ja ripulin välillä ei ollut havaittavissa mitään yhteyttä. Vaikka rotuyhdistelmissä oli jonkin verran eroja ripuliin sairastuvuudessa, ei ripulin huomioon ottaminen tilastollisessa mallissa vaikuttanut rotuyhdistelmien eroihin. Koska ripulihavainnot olivat pahnue/karsinakohtaisia, ne eivät täysin kuvaa yksittäisen eläimen sairastavuutta ja sen vaikutusta mitattuihin ominaisuuksiin. Vaikka ripulin esiintyvyydessä oli rotuyhdistelmien välillä jonkin verran eroja (Niemi ym. 2010), ripulin huomioon ottaminen ei muuttanut rotuyhdistelmien LS-estimaattien arvoja eikä siten myöskään arvoja tarkastelluissa lihasikaominaisuuksissa.

\section{Johtopäätökset}

Ripulihavainnot olivat yleisimpiä pian vieroituksen jälkeen ja vähenivät nopeasti ensimmäisten viikkojen jälkeen. Tässä tutkimuksessa vieroitusripuli ei näyttänyt vaikuttavan sikojen myöhempään kasvuun eikä siten vaikuttanut kokeen varsinaiseen tavoitteeseen eli rotuyhdistelmien vertailuun. Ainoastaan erittäin pitkittyneestä ja vaikeasta ripulista oireilleiden karsinoiden porsaiden kasvunopeus vieroituksesta teurastukseen oli jonkin verran heikentynyt. Analysointia vaikeutti ripulihavaintojen kirjaaminen vain karsinoittain, siksi tulokset ovat vain suuntaa antavia.

\section{Kirjallisuus}

Niemi, J., Partanen, K., Puolanne, E., Ruusunen, M., Sevón-Aimonen, M.-L., Voutila, L., Siljander-Rasi \& H., Serenius, T. 2010. Sikarotyhdistelmien erot tuotanto- ja lihan laatuominaisuuksissa ja erojen taloudellinen merkitys. 28 p. (Tutkimushankkeen loppuraportti 30.6.2010 MAKERA Dnro 4519/502/2006). [Url] 